\title{
Strategi Guru Bimbingan Dan Konseling (BK) Dalam Membantu Mengatasi Kesulitan Belajar Siswa MTs Daruth Tholibiin Nganjuk
}

\author{
Moh. Nasrulloh, ${ }^{1}$ Muslimin ${ }^{2}$ \\ ${ }^{1}$ Pascasarjana Institut Agama Islam Tribakti Kediri, ${ }^{2}$ Institut Agama Islam Tribakti Kediri \\ 1nasrulloh@gmail.com, ${ }^{2}$ musliminiait@gmail.com
}

\begin{abstract}
This study wants to see the effect of BK on overcoming student learning difficulties at MTs Daruth Tholibiin Nganjuk. Learning difficulties are naturally experienced by all students, but not all schools or teachers are able to help students overcome these problems. Almost all schools also have counselling guidance teachers. However, in practice, BK teachers also have differences in dealing with student problems. Because of different cultures, habits and situations. In this study using a qualitative approach, because the qualitative approach has characteristics including natural setting and researchers as key instruments, descriptive research and inductive data analysis. In collecting data using the method of observation, interviews and documentation. While the data analysis uses descriptive qualitative techniques. From this study, it can be concluded how the teacher guidance and counselling strategy in overcoming the learning difficulties of MTs Daruth Tholibiin students. Guidance and counselling (BK) teacher strategies in helping students overcome learning difficulties are carried out through classical learning orientation and information during one hour of learning, holding counselling in a special room for guidance and counselling services, conducting case conferences and holding follow-up in collaboration with teachers in the field of study and parents of students.
\end{abstract}

Keywords: Teacher Strategy, Counseling Guidance, Learning Difficulties

\begin{abstract}
Abstrak
Penelitian ini ingin melihat pengaruh BK dalam mengatasi kesulitan belajar siswa di MTs Daruth Tholibiin Nganjuk. Kesulitan belajar tentu dialami oleh semua siswa, akan tetapi tidak semua sekolah atau guru mampu mambantu siswa mengatasi masalah tersebut. Hampir semua sekolah pun memiliki guru bimbingan konseling. Akan tetapi, secara praktik, guru-guru BK pun mempunyai perbedaan dalam menghadapi masalah siswa. Karena kultur, kebiasaan dan situasi yang berbeda. Dalam penelitian ini menggunakan pendekatan kualitatif, karena pendekatan kualitatif mempunyai ciri-ciri antara lain: latar alami dan peneliti sebagai instrumen kunci, penelitian bersifat deskriptif dan analisa data secara induktif. Dalam pengumpulan datanya menggunakan metode observasi, wawancara dan dokumentasi. Sedangkan analisa data menggunakan tehnik deskriptif kualitatif. Dari penelitian ini dapat disimpulkan bagaimana strategi guru bimbingan dan
\end{abstract}


konseling dalam mengatasi kesulitan belajar siswa MTs Daruth Tholibiin. Strategi guru bimbingan dan konseling (BK) dalam membantu mengatasi kesulitan belajar siswa dilakukan melalui orientasi dan informasi belajar secara klasikal selama satu jam pelajaran, mengadakan konseling diruang khusus pelayanan bimbingan dan konseling, melaksanakan konferensi kasus dan mengadakan tindak lanjut dengan bekerjasama dengan guru bidang studi dan oran tua siswa.

\section{Kata Kunci: Strategi Guru, Bimbingan Konseling, Keesulitan Belajar}

\section{Pendahuluan}

Guru bimbingan konseling (BK), mempunyai kesamaan tanggung jawab peran dan fungsi seperti guru-guru mata pelajaran lain. Ia mempunyai kewajiban menyukseskan tujuan pendidikan nasional. meskipun tidak bisa dipungkiri, terkadang beban pekerjaanya lebih banyak. Sejatinya, guru BK pun mempunyai peran dan fungsi penting juga dalam penyelenggaraan pendidikan. Tujuan lebih jauh adalah mengembangkan pengetahuan pendidikan.

Secara rasional semua ilmu pengetahuan dapat diperoleh melalui belajar. Maka, belajar adalah "key term" (istilah kunci) yang paling vital dalam usaha pendidikan. Sehingga, tanpa belajar sesungguhnya tidak pernah ada pendidikan. ${ }^{1}$ Menurut Ahmad Tafsir, pengetahuan tidak pernah bisa diakui secara ilmiah, jika tidak berada pada ranah pendidikan. Ilmu pengetahuan yang berasal dari rahim pendidikan. Dalam konteks inilah, pendidikan juga dimaknai sebagai pengembangan pengetahuan. ${ }^{2}$

${ }^{1}$ Muhibbin Syah, Psikologi Belajar (Jakarta: PT. RajaGrafindo Persada, 2004), Cet.3, h. 59.

2 Ahmad Tafsir, Filsafat Ilmu, (Jakarta: Pustaka Pelajar, 2002), h, 30.
Oleh karena itu, belajar ini dilakukan oleh manusia berlangsung terus-menerus, sepanjang hayat (life long education), di sekolah maupun di luar sekolah, dibimbing atau tidak. Premis ini diperkuat oleh kenyataan bahwa manusia walaupun mempunyai kelemahan, tetapi di sisi lain ia adalah makhluk yang dinamis bukan makhluk yang statis. $^{3}$

Belajar mempunyai tingkat hambatan yang muncul dari beragam faktor. Secara umum, ada dua faktor yang mempengaruhi tingkat belajar siswa, pertama faktor internal, misalnya kecacatan fisik atau mental, kedua faktor eksternal, misalnya lingkungan yang tidak mendukung belajar siswa. Kedua faktor ini mempengaruhi perkembangan belajar yang berdampak pada hasil belajar siswa. Hal ini yang juga dapat dilihat pada siswa MTs. Daruth Tholibin Nganjuk.

Sejatinya, kenakalan dikalangan anak remaja, merupakan masalah sosial yang tak dapat dipungkiri, suatu masalah sosial yang sangat memerlukan perhatian

3 Abd. Rahman Abror, Psikologi Pendidikan (Yogyakarta: PT. Tiara Wacana, 1993), h. 63. 
karena sangat mengkhawatirkan, dikatakan mengkhawatirkan karena banyak dari kasus kenakalan remaja telah menjurus ke arah kejahatan. Para remaja melakukan tindakan di luar batas, menyimpang dari norma dan tata tertib masyarakat. Berbagai kasus kenakalan remaja yang terjadi menimbulkan ketakutan dan kekhawatiran di masyarakat, timbulnya masalah yang lebih rumit dan tampaknya semakin sering terjadi.

Adanya iklim lingkungan kehidupan yang kurang sehat, seperti: maraknya tayangan pornografi, kekerasan di televisi, minuman-minuman keras, perjudian, obatobat terlarang atau narkoba, ketidak-harmonisan dalam kehidupan keluarga dan lainnya yang sangat mempengaruhi pola perilaku atau gaya hidup terutama pada usia remaja yang cenderung menyimpang dari kaidahkaidah moral (akhlak yang mulia), bergaya hidup mewah, serta persoalan fashion yang identik dengan trend pakaian-pakaian mini, ketat, aksesorisaksesoris yang mahal, make- up berlebihan yang semuanya itu belum tentu ada manfaatnya hal tersebut merupakan gambaran pola hidup sebagian remaja saat ini.

Tindakan-tindakan di atas, menjadi tugas utama guru BK. Padahal di luar semua itu, anak-anak mempunyai kemampuan secara skill maupun kecerdasan intelektual. Seperti yang peneliti ketemukan pada umumnya yang dialami oleh siswa MTs Daruth Tholibin Jatisari Lengkong dalam kegiatan belajar, banyak siswa yang belum mampu mengoptimalkan kemampuan/potensi tiga ranah tersebut diatas yang dimiliki para siswa, sehingga hasil belajar yang dicapai kurang optimal

\section{Metode}

Sesuai dengan judul penelitian ini yaitu "Strategi Guru Bimbingan Dan Konseling (BK) Dalam Membantu Mengatasi Kesulitan Belajar Siswa di MTs Daruth Tholibiin Nganjuk", maka penelitian ini termasuk penelitian yang menggunakan pendekatan kualitatif, yaitu suatu prosedur penelitian yang mendeskripsikan prilaku orang, peristiwa, atau tempat tertentu secara rinci dan mendalam.

Dimana penelitian deskriptif merupakan penelitian yang non hipotesis sehingga dalam langkah penelitiannya tidak perlu merumuskan hipotesis. Dalam hal ini peneliti hanya ingin mengetahui hal-hal yang berhubungan dengan keadaan sesuatu berdasarkan data-data 4 .

Penelitian ini dilaksanakan di MTs Daruth Tholibiin Nganjuk sebagai lokasi penelitian yang terletak di Dusun Jatisari Desa Jatipunggur Kecamatan Lengkong Kabupaten Nganjuk, dengan pertimbangan, para siswa sering membolos dan berkeliaran di sekitar rumah peneliti. Mengingat MTs Daruth Tholibiin adalah

${ }^{4}$ Arief Furchan, Pengantar Penelitian dalam Pendidikan (Surabaya : Usaha Nasional, 1982), h. $\underline{414}$ 
sekolahan swasta yang muatan ajaran agamanya terkenal lebih banyak dibanding dengan sekolahan lain.

Dalam penelitian ini, peneliti bertindak sebagai subjek penelitian yang bekerjasama dengan guru bimbingan dan konseling (BK), guru bidang studi, siswa serta orang tua siswa untuk mengadakan observasi lapangan kepada unsur penelitian dengan memberikan angket yang berisi beberapa pertanyaan yang harus diisi oleh siswa dan peneliti juga melakukan wawancara langsung kepada objek penelitian.

Data dalam penelitian ini adalah semua data atau informasi yang diperoleh dari para informan (kepala sekolah, siswa, guru bimbingan dan konseling (BK), guru bidang studi) yang dianggap paling mengetahui dengan jelas mengenai fokus penelitian yang diteliti, dat juga diperoleh dari dokumentasi yang menunjang terhadap fokus penelitian.

Selanjutnya cara untuk mengkoordinasikan data penelitian dapat ditempuh dengan cara sebagai berikut : Pertama, membaca seluruh catatan lapangan dan melakukan analisis awal dan penelitian. Kedua, mengelompokkan data atau informasi sesuai dengan fokus studi. Ketiga, memahami masing-masing fokus studi untuk mengetahui rumusan masalah yang diajukan dalam penelitian.

Tahap sebelum ke lapangan meliputi: menyusun proposal penelitian, menentukan fokus penelitian, konsultasi fokus penelitian kepada pembimbing, mengurus surat izin dan seminar proposal penelitian. Tahap pekerjaan lapangan meliputi: pengumpulan data atau informasi yang terkait dengan fokus penelitian dan pencatatan data. Tahap analisis data meliputi: organisasi data, penafsiran data, pengecekan keabsahan data dan memberi makna. Tahap penulisan laporan meliputi : penyusuna hasil penelitian, konsultasi hasil penelitian kepada pembimbing, perbaikan hasil konsultasi, pengurusan kelengkapan persyaratan ujian dan ujian Tesis.

\section{Hasil dan Pembahasan}

Pengertian Bimbingan adalah bantuan atau pertolongan yang diberikan kepada individu atau sekumpulan individu dalam menghindari atau mengatasi kesulitan-kesulitan di dalam hidupnya, agar individu tersebut dapat mencapai kesejahteraan hidupnya. Sedangkan pengertian penyuluhan adalah proses pemberian bantuan yang dilakukan melalui wawancara konseling kepada individu yang mengalami suatu masalah $^{5}$.

Pentingnya siswa untuk memahami dan mengenal dirinya dengan sebaik-baiknya agar dapat mengembangkan kemampuannya dan mengatasi berbagai kesulitan-kesulitan yang dialaminya baik yang berhubungan dengan masalah belajar, sosial maupun masalah kariernya untuk merealisasikan dirinya sesuai dengan potensinya dalam 
mencapai penyesuaian diri dengan lingkungannya

Guru bimbingan dan konseling (BK) adalah seorang tenaga profesional baik pria atau wanita yang memperoleh pendidikan khusus diperguruan tinggi dan idealnya berijazah sarjana dari FIP IKIP Jurusan Psikologi dan Bimbingan yang mencurahkan waktunya pada pelayanan bimbingan.

Tugas seorang guru bimbingan dan konseling (BK) adalah turut melancarkan program pendidikan di sekolah, bertanggung jawab atas keseluruhan program layanan bimbingan dan konseling serta memberikan informasi terbaru berupa pemilihan program studi lanjut, pekerjaan dan bentuk kerjasama yang baik antara kepala sekolah, guru, orang tua dan siswa.

Kesulitan belajar adalah suatu kondisi dalam proses belajar yang ditandai oleh kesulitan dalam tugastugas akademik atau menguasai bahan pelajaran yang diajarkan. Faktor-faktor penyebab kesulitan belajar ada dua yaitu faktor intern yang meliputi gangguan pada psiko-fisik siswa (kognisi, afeksi dan psikomotor) dan faktor ekstern yang meliputi semua kondisi lingkungan di sekitar yang tidak mendukung kegiatan belajar siswa (keluarga, masyarakat, sekolah).

Berbagai materi pembelajaran sebagai strategi guru bimbingan dan konseling (BK) dalam membantu mengatasi kesulitan belajar siswa dapat dilakukan secara kelompok, individual ataupun klasikal yang sengaja dibentuk untuk mengembangkan motivasi, sikap dan kebiasaan belajar yang baik dan memberikan ketrampilan belajar tertentu sesuai dengan kondisi siswa dan masalah yang dihadapi. Demikian individual (dilakukan wawancara konseling) dapat ditempuh untuk mengembangkan berbagai materi tersebut, yang diharapkan hasilnya akan lebih mantap terhadap siswa yang bermasalah untuk dapat meningkatkan prestasi belajarnya.

Pondok Pesantren Daruth Tholibiin merupakan lembaga pendidikan islam yang sekarang dibawah naungan Yayasan Pendidikan dan Sosial (YPS) Daruth Tholibiin yang terletak di Dusun Jatrisari Desa Jatipunggur Kecamatan Lengkong.

\section{Analisis}

Tanah yang dimiliki Pondok Pesantren Daruth Tholibiin awalnya merupakan tanah wakaf dari Bapak K. Zainudin yang selanjutnya lokasi tersebut diperluas dan berada dibawah naungan YPS Daruth Tholibiin dengan mendirikan lembaga lain seperti TPA, MADIN, PAUD, RA, dan Madrasah Ibtidaiyah yang kini telah berkembang pesat menjadi MI Islamiyah. Yayasan ini kurang lebih berdiri pada tahun 1980 dan diketuai oleh Bapak Mastohar.

Untuk memantapkan perjalanan yayasan maka MI Islamiyah didaftarkan menjadi lembaga berbadan hukum bernomor 04 dan ditandatangani oleh Widji Winarsih, S.H. Pada tahun 2000 MI Islamiyah yang awalnya masuk sore berubah menjadi masuk pagi dengan 
jumlah siswa 18 dengan gedung seadanya. Baru pada tahun 2002 dan 2005 mendapat bantuan gedung dari pemerintah sebanyak 4 lokal.

Pada tahun 2004 MI Islamiyah mendapat status terakreditasi dengan nilai B, sampai saat ini jumlah siswa mencapai 130 siswa dan telah meluluskan $100 \%$, serta meraih juara I dan III lomba tartil, juara I lomba baca puisi, juara I lomba pidato serta juara III lomba gerak jalan di tingkat kecamatan, dan masih ada banyak lagi.

Melihat perkembangan yang sangat pesat dan dengan dorongan masyarakat setempat, maka para pengurus Yayasan Pendidikan dan Sosial Daruth Tholibiin mengadakan musyawaroh untuk mendirikan MTs Daruth Tholibiin, maka pada tahun 2007 Berdirilah MTs Daruth Tholibiin yang saat itu masih kelas VII dengan jumlah siswa 23 yang dikepalai sekolah oleh Bpk. Ali Muntaha

Dengan perjuangan para pendiri lembaga yang tak kenal lelah demi terciptanya suatu desa yang akhirnya akan menjadi central education yang jauh dari pusat perkotaan akhirnya MTs Daruth Tholibiin membuktikan kepada masyarakat dengan perkembangannya.

Atas perkembangan tersebut membuahkan hasil yang memuaskan dengan dibuktikan pada tahun 2017 atau kelas VIII MTs Daruth Tholibiin ini

6 Wawancara dengan kepala sekolah di kantor MTs Daruth Tholibiin pada Tanggal 21 Agustus 2019 jam 09:40 s/d 10:55

7 Wawancara dengan Sri Wulaningsih, pada Tanggal 21 Agustus 2019 jam 11:00 s/d 11:45 mendapatkan 129 siswa sampai sekarang. ${ }^{6}$

Berdasarkan dokumentasi yang peneliti peroleh dari lokasi penelitian, MTs Daruth Tholibiin Jatisari ini sudah memiliki 6 kelas yang sudah mendapat izin operasional, yang mana pada kelas VII terbagi menjadi 2 bagian, kelas VIII terbagi menjadi 2 bagian dan kelas IX terbagi menjadi 2 bagian.

Berbicara mengenai kesulitan belajar siswa di MTs Daruth Tholibiin Jatisari Lengkong ini, dari hasil wawancara yang peniliti lakukan dengan guru bimbingan dan konseling (BK), siswa yang mengalami kesulitan belajar dan guru bidang studi dapat diketahui bahwa:

a. Motivasi belajar rendah disebabkan Karena "adanya cita-cita yang belum terbentuk sehingga siswa malas belajar, membolos dan kurang berusaha dalam belajar" ${ }^{7}$ Kurangnya perlengkapan belajar yang menyebabkan siswa kurang termotivasi dalam belajar. Siswa kurang termotivasi untuk belajar karena "kurang adanya minat untuk mempelajari materi pelajaran dengan sungguh-sungguh".8 "Pada saat proses belajar mengajar berlangsung dikelas siswa bermain atau bicara dengan teman sebangku serta tidak ikut jam pelajaran dengan alasan

${ }^{8}$ Wawancara dengan Siti Maisyaroh, S.Pd.I Guru Bahasa Indonesia di Kantor MTs Daruth Tholibiin pada tanggal 21 Agustus 2019 jam 2017 jam 09:00 s/d 09:45 
kekamar kecil". 9 Kebanyakan siswa tidak suka dengan sikap guru sehingga tidak minat atau kurang termotivasi dalam belajarnya.

b. Sikap dan kebiasaan buruk dalam belajar ditandai dengan sikap siswa yang malas belajar, malas untuk masuk kelas dan kurang suka terhadap guru. "Kebiasaan yang buruk dari siswa dengan melakukan pengingkaran terhadap jadwal pelajaran, meremehkan pelajaran dan tidak mau memanfaatkan sumber belajar seperti buku-buku perpustakaan". 10

"Di dalam kelas ketika proses belajar mengajar berlangsung mereka acuh tak acuh terhadap pelajaran karena benci terhadap pelajaran tersebut, tidak mau bertanya tentang hal yang tidak diketahui, catatan pelajaran tidak lengkap dan sering menunda menyelesaikan PR." 11

c. Daya serap rendah, hal ini ditunjukan siswa kurang mampu memahami pelajaran yang disampaikan oleh guru, sehingga siswa tidak dapat menyerap materi secara optimal. Dalam kelas pada saat proses belajar mengajar anak kurang bisa konsentrasi, apabila guru bertanya siswa menjawab tidak sesuai dengan jawaban yang diharapkan. “Dengan

${ }^{9}$ Wawancara dengan Amir Hidayat, S.Pd.I Guru SAIN, di Kantor MTs Daruth Tolibiin pada tanggal 21 Agustus 2019 jam 11:00 s/d 11:45

10 Wawancara dengan Sri Wulaningsih,S.Pd.I Guru BP di Kantor MTs Daruth Tholibiin pada tanggal 21 Agustus 2019 jam 09:50 s/d 11:00 latar belakang daya serap rendah kebanyakan anak malas untuk belajar dengan giat karena kurang paham dengan keterangan yang diberikan oleh guru". 12

Siswa yang mengalami kesulitan belajar, timbul dari factor intern dan ekstern siswa. Berdasarkan dari hasil wawancara yang peneliti lakukan dengan siswa-siswi yang mengalami kesulitan belajar dapat diketahui bahwa factor penyebab kesulitan dari intern siswa adalah "siswa kurang berminat terhadap suatu mata pelajaran terutama ekstra, belajar yang kurang terjadwal, malas mengerjakan tugas-tugas atau suka menunda-nunda tugas sekolah, tidak suka dengan guru bidang studi." Sedangkan factor ekstern berasal dari lingkungan keluarga yaitu terlalu banyak saudara, orang tua yang cenderung kurang memperhatikan belajar anak di rumah karena sibuk bekerja.

Dari lingkungan sekolah timbul dari guru mata pelajaran dimana menerapkan suatu metode mengajar yang kurang menarik, sikap dan perilaku guru yang kurang memotivasi belajar siswa, adanya

11 Wawancara dengan Nur Qolis, Junda Arya, Hamdan, siswa yang mengalami kesulitan belajar di kantin sekolah pada tanggal 21 Agustus 2019 jam 09:00 s/d 09:45

12 Wawancara dengan Amir Hidayat,S.Pd.I, guru SAIN di Kantor MTs Daruth Tholibiin pada tanggal 21 Agustus 2019 jam 11:00 s/d 11:75 
hubungan yang kurang harmonis antara guru dan siswa".13

Untuk membantu mengatasi kesulitan belajar siswa, guru bimbingan dan konseling (BK) melakukan identifikasi siswa yang berkasus (kesulitan belajar) dengan cara pengamatan langsung di kelas, melihat hasil ulangan harian. Mid atau raport. Identifikasi ini dilakukan oleh guru bidang studi pada saat proses belajar mengajar berlangsung, dilihat dari catatan pelajaran, hasil dari tugas yang diberikan guru melalui LKS. Kemudian anak yang mengalami kesulitan belajar dilaporkan keguru wali kelas dan baru ke guru bimbingan dan konseling (BK) untuk dibantu menyelesaikan masalahnya secara lanjut. Dimana guru bimbingan dan konseling (BK) mencatat siswa yang memerlukan bimbingan, kemudian mengumpulkan data-data yang berhubungan dengan siswa yang diperoleh dari dokumentasi siswa. "Observasi dan informasi yang diperoleh dari guru bidang studi dan wali kelas". ${ }^{14}$ Untuk mendapatkan hasil yang maksimal dari pelaksanaan program bantuan tersebut harus dilaksanakan secara sistematis dan kontinyu. Adapun program bantuan tersebut adalah:
Orientasi dan Informasi Cara Belajar Serta Evaluasi Cara Belajar

Kegiatan ini dimaksudkan untuk membantu siswa agar mereka mampu mengevaluasi cara belajar yang telah mereka laksanakan serta mengevaluasi kembali hasil belajar yang telah mereka peroleh sebelumnya. Sehingga siswa akan melihat kembali, merevisi atau mungkin akan meningkatkan cara belajar mereka yang dilakukan dengan cara:

1) Membenahi jadwal belajarnya

2) Mengubah cara atau kebiasaan belajar dan atau meningkatkan waktunya

3) Mengurangi/menghilangkan Kendala yang dihadapi siswa

4) Meningkatkan motivasi belajar siswa. ${ }^{15}$

Menurut Ibu Sriwulaningsih mnyatakan bahwa kegiatan ini dilaksanakan secara klasikal selama 1 jam pelajaran setiap minggunya dengan mengguanakan buku LKS.

a. Konseling

Kegiatan ini merupakan bentuk khusus yang bertujuan membantu siswa baik secara individual maupun kelompok yang mempunyai persamaan permasalahan, agar mereka dapat memcahkan masalah sendiri sehingga dapat meniongkatkan prestasi belajarnya. Adapun pemberian bantuan-bantuan tersebut melalui tahap-tahap pemahaman diri, lingkungan, penyesuaian diri

Daruth Tholibiin pada tanggal 21 Agustus 2019 09:50 s/d 11:00

15 Program Kerja BK Mts Daruth Tholibiin Guru SAIN di kantor MTs Daruth Tholibiin pada tanggal 21 Agustus 2019 jam 11:00 s/d 11:75 Wawancara dengan Sri wulaningsih,S.Pd.I, Guru BK di kantor MTs
Tahun Ajaran 2019/2020 
dan pemecahan masalaholeh siswa itu sendiri. Dengan pendekatan yang digunakan melalui wawancara konseling secara individu atau kelompok pada setiap saat dalam suatu ruangan khusus yang pelaksanaannya secara directive (guru bimbingan dan konseling (BK) memberi pengarahan kepada siswa dalam pemecahan masalahnya), non directive (siswa yang diberi konselling yang memilih penyelesaian masalah yang telah dikemukakan sendiri kepada guru bimbingan dan konseling (BK)), corrective sesuai dengan keadaan atau situasi konseling. ${ }^{16}$

\section{b. Konferensi Kasus}

Konferensi kasus adalah suatu konferensi tentang individu yang bermasalah. Suatu studi kelompok tentang individu yang perlu mendapatkan bantuan dalam pemecahan masalahnya. Tujuannya untuk mengatasi masalah kusus dengan mengambil keputusan secara bersama dari berbagai pihak terkait dengan kasus siswa yang sedang dibahas melalui diskusi atau problem solving. ${ }^{17}$

Yang menjadi objek konferensi kasus adalah siswa yang mengalami kesulitan belajar. Jadi siswa tersebut membutuhkan pelayanan kusus dan perlu dibahas kasusnya. Bentuk konferensi kasusyang dilakukan dengan cara membahas kasus yang terjadi dengan guru bimbingan dan konseling (BK) sebagai pemrakarsanya.

16 Program Kerja BK Mts Daruth Tholibiin Tahun Ajaran 2019/2020 10

17 Program Kerja BK Mts Daruth Tholibiin Tahun Ajaran 2019/2020, 12
Semua yang terlibat salig memberikan informasi tentang anak yang mengalami masalah dalam belajarnya, kemudian diupayakan untuk menemukan solusi terbaik dalam penyelesaian kasus.

Penyelesaian yang dilakukan adalah dengan membuat kesepakatan tentang tindakan bantuan yang akan diberikan kepada siswa dengan bimbingan belajar yaitu "memberikan informasi cara-cara belajar yang efektif dan efisien, memberikan informasi pemanfaatn perpustakaan, pembuatan jadwal belajar siswa, koordinasi dengan orang tua untuk mengawasi kegiatan belajar anaknya di rumah dan anjuran kepada siswa untuk ikut les tambahan diluar sekolah". ${ }^{18}$

\section{Kesimpulan}

Bimbingan dan konselling (BK) merupakan suatu usaha untuk membantu mengatasi kesulitan belajar siswa yang dialami oleh siswa Mts Daruth Tholibiin Jatisari terutama dalam masalah belajarnya sehingga dapat mencapai harapan-harapannya dan terselesainya kesulitan-kesulitan tersebut.

Berdasarkan kajian tersebut, penulis dapat menarik kesimpulan bahwa:

1. Bentuk kesulitan belajar yang dialami oleh siswa MTs Daruth Tholibiin Jatisari ada 3 jenis yaitu: motivasi belajar rendah, sikap dan kebiasaan yang buruk dalam belajar dan daya serap rendah sehingga berakibat

18 Wawancara dengan Sri wulaningsih,S.Pd.I, Guru BP di kantor MTs Daruth Tholibiin pada tanggal 21 Agustus 2019 09:50 s/d 11:00 
prestasi belajarnya rendah. Adapun faktor faktor yang menyebabkan kesulitan belajar siswa ada 2 faktor yaitu:

a. Faktor intern meliputi: minat belajar rendah, kurang berusaha dalam belajar, mengingkari tanggung jawab.

b. sedangkan faktor ekstern meliputi : lingkungan keluarga terutama orang tua yang kurang dalam mengawasi anaknya belajar di rumah, lingkungan sekolah itu sendiri yang datang dari guru bidang studi.

2. Macam-macam strategi yang digunakan dalam membantu mengatasi kesulitan belajar siswa:

1) Orientasi dan Informasi Belajar

2) Konseling

3) Konferensi Kasus

4) Tindak Lanjut

\section{Daftar Pustaka}

Syah, Muhibbin, Psikologi Belajar, Jakarta: PT. RajaGrafindo Persada, 2004

Tafsir, Ahmad, Filsafat Ilmu, Jakarta: Pustaka Pelajar, 2002

Abror, Abd. Rahman, Psikologi Pendidikan Yogyakarta: PT. Tiara Wacana, 1993

Furchan, Arief, Pengantar Penelitian dalam Pendidikan, Surabaya : Usaha Nasional, 1982

Priyatno, Dasar-dasar Bimbingan dan Konseling, Jakarta: Rineka Cipta, 1999
Program Kerja BK Mts Daruth Tholibiin Tahun Ajaran 2019/2020

Program Kerja BK Mts Daruth Tholibiin Tahun Ajaran 2019/2020 10

Program Kerja BK Mts Daruth Tholibiin Tahun Ajaran 2019/2020, 12

Program Kerja BK Mts Daruth Tholibiin Tahun Ajaran 2019/2020

Slameto, Belajar Dan Faktor-Faktor Yang Mempengaruhi, Jakarta: Rineka Cipta, 2015 